\title{
Molecular Weight and Degree of Methoxylation in Cell Wall Polyuronide during Softening in Pear and Apple Fruit
}

\author{
H. Yoshioka, K. Aoba, and Y. Kashimura \\ Morioka Branch, Fruit Tree Research Station, Ministry of Agriculture, Forestry and Fisheries, \\ Shimokuriyagawa Morioka, Japan \\ Additional index words. pectin, pectinmethylesterase, polysaccharide, ripening, polygalacturonase, Malus domestica, \\ Pyrus communis
}

\begin{abstract}
The concentrations of water-soluble polyuronides in apples [Malus domestica Borkh.) and pears (Pyrus communis L.) increased, but those of EDTA- and HCl-soluble polyuronides decreased during softening. Total polyuronide content decreased slightly during softening in both fruits. Depolymerization of polyuronides was observed only in the water-soluble fraction in pear fruit during softening, concomitant with an increase in polygalacturonase (PG) activity. No detectable depolymerization was observed in any of the polyuronide fractions during softening of apple fruit nor was any PG activity detected. The polyuronide fractions extracted from pear and apple cell walls contained various amounts of methoxyl groups. Polyuronides with a high degree of methoxylation were preferentially lost from EDTA- and HCl-soluble polyuronides during softening of both fruit. The water-soluble polyuronide had a lower degree of methoxylation than those lost in the EDTA- and HCl-soluble fractions. These results suggest de-esterification of polyuronides with a high degree of methoxylation rather than the depolymerization of polyuronides in the solubilization of polyuronides during ripening of apples and pears.
\end{abstract}

Fruit softening is attributed to the dissolution of cell wall components, particularly polyuronides (Huber, 1983; Pilnik and Voragen, 1970). Solubilization of polyuronides in ripening fruit is related to the depolymerization of polyuronide by the action of polygalacturonase (PG, EC 3.2.1.15) (Huber, 1983). Recently, work with a transgenic tomato (Lycopersicon esculentum Mill.) has led to questioning the role of PG in softening (Christopher et al., 1990; Giovannoni et al., 1989; Smith et al., 1988). Tomato fruit engineered to express antisense PG RNA developed only $1 \%$ of its normal level of PG and were inhibited in their depolymerization of polyuronide during ripening. However, softening and polyuronide solubilization were not affected by expression of the antisense PG (Christopher et al., 1990). Release of polymeric polyuronide occurs in the absence of PG in strawberry (Fragaria $\times$ ananassa Duch.) (Barnes and Patchett, 1976; Huber, 1984; Neal, 1965), apple (Bartley, 1978; Pilnik and Voragen, 1970), and muskmelon (Cucumis melo L.) (Hobson, 1962; Lester and Dunlop, 1985; McCollumn et al., 1989) during fruit softening. Consequently, a consistent explanation is needed for the mechanism of polyuronide solubilization during fruit softening other than that of PG action. Some hypotheses suggest modification of noncellulosic neutral sugar components of the wall (Gross and Sams, 1984; Knee, 1973; Knee et al., 1977; McCollumn et al., 1989; Wanner and Bloom, 1977), synthesis of modified types of polymers (Huber, 1984; Knee, 1978; Mitcham et al., 1989), and involvement of calcium mobility (Pooviah et al., 1988; Rigney and Wills, 1981; Suwwan and Pooviah, 1978).

In this study, we attempt to 1) test whether depolymerization of the polyuronide is concerned with the solubilization of the polyuronides or not, and 2) investigate the involvement of poly-

\footnotetext{
Received for publication 2 July 1991. Accepted for publication 4 Feb. 1992. This paper is contribution no. C-161 of Fruit Tree Research Station. We thank T. Kubota and his staff, National Farmers' Academy of Deciduous Fruit Trees Training Center, for kindly providing the pears and $\mathrm{T}$. Itoh for her technical assistance. The cost of publishing this paper was defrayed in part by the payment of page charges. Under postal regulations, this paper therefore must be hereby marked advertisement solely to indicate this fact.
}

uronide de-esterification in fruit softening, using pears that contain PG and apples that do not.

\section{Materials and Methods}

Mature-green 'Red Bartlett' pears were obtained from an orchard at the National Farmers' Academy of Deciduous Trees Training Center, Iwate, Japan. 'Redgold' apples were grown in our experimental orchard. Fruits were picked at their commercial harvest based on ground color. They were selected for uniformity of size and freedom from blemishes. Pears were stored at $2 \mathrm{C}$ for 1 week before use, and then ripened at 20C. Apple fruits were ripened at $25 \mathrm{C}$ to accerelate softening immediately after harvest. Humidity of the ripening chamber was maintained at $95 \%$. Four fruits were sampled on each occasion: pears at 2day intervals and apples at 5-day intervals. The experiments were done three times.

The ethylene concentration in the central core of the fruit was determined by gas chromatography in $0.5-\mathrm{ml}$ gas samples drawn from the fruit with needle and syringe. Fruit firmness was determined with a fruit pressure tester FT-327 (Effegi, Italy) with an 11-mm plunger. Enzyme solution was extracted from the cell wall fraction of the pulp tissue with $1.0 \mathrm{M} \mathrm{NaCl}$ as described by Nawa et al. (1980).

PG activity was determined by the reduction of viscosity in the assay mixture; a $5.0-\mathrm{ml}$ aliquot contained $1.5 \%$ sodium polygalacturonate (Sigma), $0.1 \mathrm{~m}$ tris-acetate $(\mathrm{pH} 5.0), 0.1 \mathrm{~mm}$ calcium chloride, and enzyme. The samples were incubated at 37C, and viscosity changes were measured by a Canon-Fenske viscometer (Shibata, Tokyo). The initial velocity was calculated from the tangent drawn to the reaction time course curve; a unit of activity was defined as the amount of enzyme that catalyzed a $1 \%$ reduction in flow time in $60 \mathrm{~min} \cdot 10 \mathrm{~g}^{-1}$ fresh weight.

Cell wall polyuronides were prepared from alcohol-insoluble residues of pulp tissues and partitioned into three fractions based on volubility in different solvents. Fresh pulp tissue was freeze-

Abbreviation: PG, polygalacturonase. 
dried and stored at $-80 \mathrm{C}$ before use. A powdered sample equivalent to $10 \mathrm{~g}$ fresh tissue was heated in $100 \mathrm{ml}$ of $80 \%$ ethanol at $80 \mathrm{C}$ for $30 \mathrm{~min}$. The homogenate was passed through a glass filter, and the residue washed twice with $50 \mathrm{ml}$ of $80 \%$ ethanol. The residue was then suspended in $100 \mathrm{ml}$ of distilled water and stirred overnight at $25 \mathrm{C}$. This mixture was centrifuged at $10,000 \times \mathrm{g}$ for $15 \mathrm{~min}$, and the pellet was washed twice with $50 \mathrm{ml}$ of distilled water and centrifuged again. The supernatants were combined and used as the water-soluble fraction. The residue was resuspended in $100 \mathrm{ml}$ of $0.05 \mathrm{M}$ EDTA in $0.05 \mathrm{M}$ sodium phosphate $(\mathrm{pH} \mathrm{4.5)}$ and heated at $80 \mathrm{C}$ for $30 \mathrm{~min}$. The suspension was centrifuged at $10,000 \times \mathrm{g}$ for $15 \mathrm{~min}$, and the pellet was washed twice with $50 \mathrm{ml}$ of EDTA solution. The supernatants were used as the EDTA-soluble fraction. The residue was resuspended in $100 \mathrm{ml}$ of $0.05 \mathrm{M} \mathrm{HCl}$ and heated at $100 \mathrm{C}$ for $1 \mathrm{~h}$. It was centrifuged and the pellet washed twice with $50 \mathrm{ml}$ of $0.05 \mathrm{M} \mathrm{HCl}$ solution. The supernatant was neutralized with Tris(hydroxymethyl)aminomethane and used as the $\mathrm{HCl}$-soluble fraction.

The molecular weight distribution of the cell wall polyuronides was estimated by gel filtration with a fast protein liquid chromatography (FPLC; Pharmacia LKB, Tokyo) equipped with a Superose $6 \mathrm{H} 10 / 30$ column equilibrated with $0.2 \mathrm{M} \mathrm{NaCl}$ in $0.15 \mathrm{M}$ citrate-sodium phosphate buffer ( $\mathrm{pH} 5.5$ ).

Cell wall polyuronides were fractionated by ion-exchange chromatography with a FPLC equipped with a DEAE-Sepharose fast flow column (Pharmacia LKB) equilibrated with $0.05 \mathrm{M}$ sodium acetate ( $\mathrm{pH}$ 5.0). The polyuronidos retained in the column were eluted with a linear gradient of $\mathrm{NaCl}(0$ to $0.4 \mathrm{M})$.

The polyuronide content was estimated by determining the uronic acid content with meta-hydroxydiphenyl as described by Blumenk-rantz and Asboe-Hansen (1973). A phenol-sulfuric acid procedure (Hedge and Hofreitor, 1962) was used for dextran determination. The degree of methoxylation was estimated by gas chromatographic (GC) determination of the methanol content of the polyuronide after the saponification with $\mathrm{NaOH}$. One milliliter of polyuronide solution containing 0.5 to $1.0 \mathrm{~mol}$ uronic acid was treated with $0.5 \mathrm{ml}$ of $0.5 \mathrm{M} \mathrm{NaOH}$ for $30 \mathrm{~min}$ at $20 \mathrm{C}$. Five microliters of solution was injected into the gas chromatograph on a $1.0 \mathrm{~m} \times 5 \mathrm{~mm}$ Porapak Q column at $100 \mathrm{C}$.

\section{Results and Discussion}

Changes in pulp firmness. Ethylene concentration in the pears increased and reached a peak more slowly and at a lower level than in apple, but pears softened more rapidly than apples (Fig.
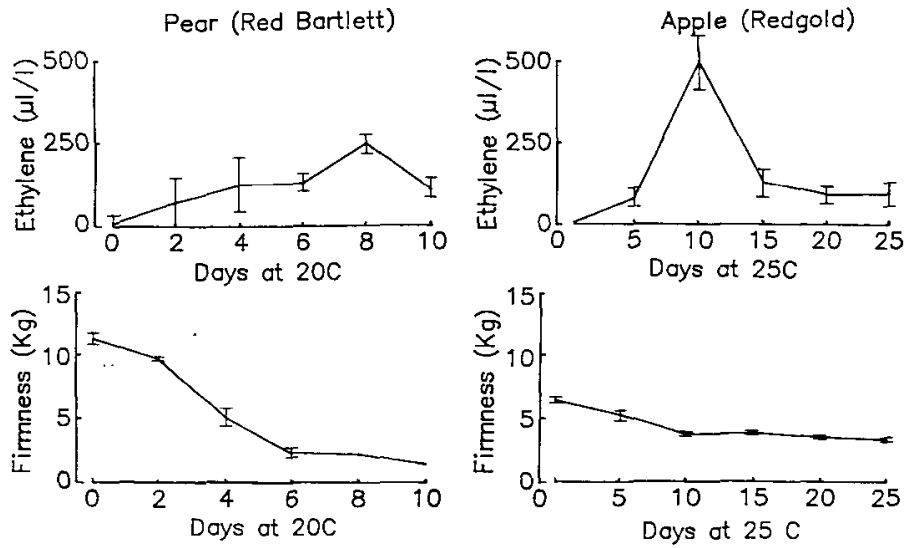

Fig. 1. Internal ethylene concentration and firmness of pears and apples during ripening. Vertical bars are sEs.
1). Pears attained a suitable eating texture after 6 days, but became over-ripe at 10 days. Apples were slightly mealy in 10 days and extremely so in 25 days.

Changes in polyuronide content and PG activiy. The concentrations of water-soluble polyuronides increased, but those of EDTA- and HCl-soluble polyuronides decreased during softening of both fruits (Fig. 2). The changes were more dramatic in pears than in apples. Total polyuronide content decreased slightly in pears and apples in the later stage of ripening. These results suggested that EDTA- and $\mathrm{HCl}$-soluble polyuronides may be converted to water-soluble polyuronide during softening.

PG activity increased significantly in pears during ripening (Fig. 3), but no detectable activity was observed in apples (data not shown).

PG is the enzyme with the most potential to solubilize polyuronide in vitro through the depolymerization of polyuronide molecules (Huber, 1983; Pilnik and Voragen, 1970). If PG activity results in polyuronide solubilization in vivo, the molecular weight distribution of the polyuronides in the cell wall should shift to a lower level as fruit softens. Consequently, the changes
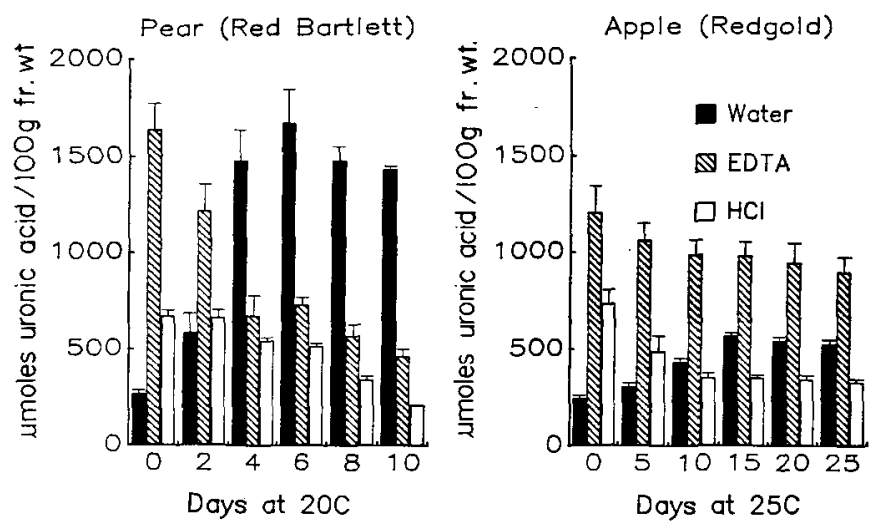

Fig. 2. Polyuronide content of cell wall fractions extracted from pear and apple pulp tissues during ripening. Alcohol-insoluble residues of the pulp tissues were sequentially extracted to yield the water-, EDTA-, and $\mathrm{HCl}$-soluble fractions. Vertical bars are sEs.

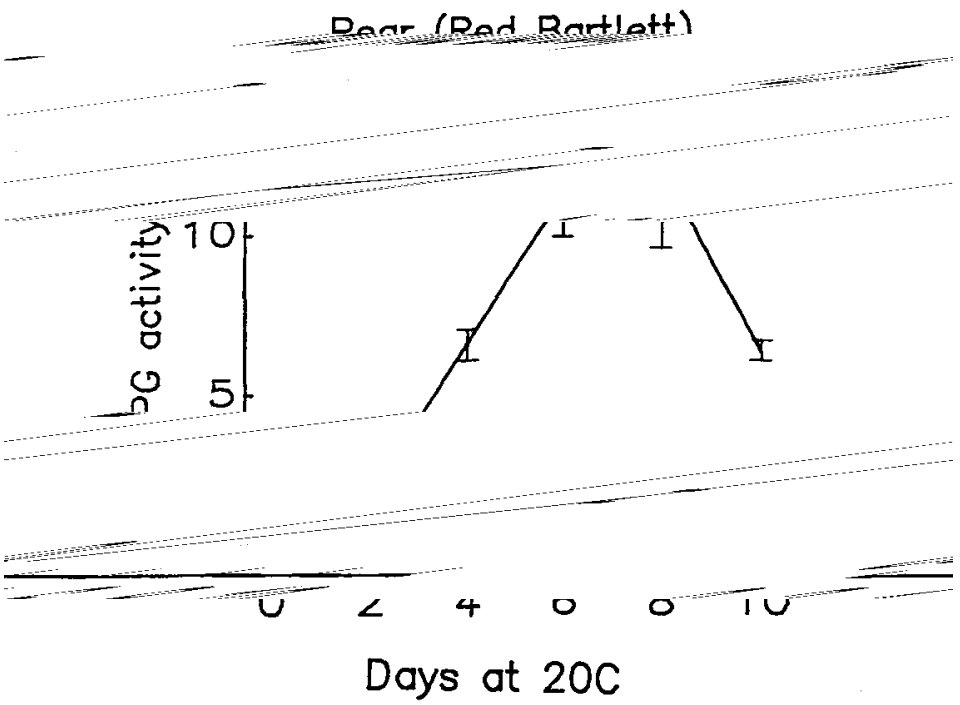

Fig. 3. PG activity in pear fruit during ripening. Enzyme solutions were prepared from pulp tissue with $1.0 \mathrm{M} \mathrm{NaCl}$ and activity determined by the decrease of viscosity in assay mixtures. Activity is expressed as $\left(\mathrm{V}_{0}-\mathrm{V}_{60}\right) /\left(\mathrm{V}_{0}-\mathrm{V}_{\text {water }}\right) \times 100 / 10 \mathrm{~g}$ fresh weight. Vertical bars are SEs. 
of the molecular weight distribution in each polyuronide fraction during softening were examined by gel filtration with Superose $6 \mathrm{H} \mathrm{10/30} \mathrm{column.}$

Molecular weight distribution of the polyuronides. Maturegreen pears (day 0) contained only, small amounts of watersoluble polyuronides of high molecular weight that were eluted at void volume and near $500 \mathrm{kDa}$ (Fig. 4). By day 4, the quantity of low- and high-molecular-weight polyuronides had increased. However, that of high-molecular-weight polyuronides had decreased while the amount of low-molecular-weight polyuronides increased as ripening continued into day 8. The EDTAand $\mathrm{HCl}$-soluble fractions from pears consisted of relatively highmolecular-weight polyuronides, and the amount of these polyuronides decreased during ripening without further changes in molecular weight. The EDTA- and $\mathrm{HCl}$-soluble polyuronides apparently do not depolymerize during softening. Also, the amount of water-soluble polyuronides with the same molecular weight coincided with those that disappeared in the EDTA- and HClsoluble polyuronides at day 4 (fraction 20-30, Fig. 4).

These results indicate that PG may act in depolymerization of the water-soluble polyuronides in pear fruit during softening; however, there is no evidence that PG may act in depolymerization of insoluble polyuronides during pear fruit softening. If insoluble polyuronides were depolymerized by PG in pear fruit, depolymerized low-molecular-weight polyuronides residues should be present in EDTA- and $\mathrm{HCl}$-soluble fractions. However, no low-molecular-weight residues existed in these fractions. All depolymerized products attacked by PG may be soluble in water so that no insoluble residue was detected in EDTA- or HClsoluble fractions during softening. However, there is no evidence that all insoluble polyuronides are solubilized after depolymerization by PG. Conversion of EDTA- and HCl-soluble polyuronides to water-soluble polyuronides in pear fruit during softening may be independent of PG action.

Apples showed an increase in water-soluble polyuronide content and a decrease in EDTA- and HCl-soluble polyuronide content, but no detectable PG activity, nor any substantial changes in molecular weight distribution during softening (Fig. 5). These results suggest that apple fruit polyuronides may be solubilized without depolymerization taking place.

Huber (1984) reported no detectable PG activity and little modification in polyuronide molecular weight with ripening of strawberry fruit and questioned the role of enzymatic hydrolysis in the increased solubility of polyuronides. McCollumn et al. (1989) reported that an increase in polyuronide solubility during muskmelon ripening was accompanied by a decrease in the molecular size of polyuronides, but no PG activity was detected. Our results with apples agree with those for strawberries.

Changes in degree of methoxylation in polyuronides. The degree of methoxylation in all polyuronide fractions decreased in pear but increased in the water-soluble fractions in apples as they ripened (Fig. 6). HCl-soluble fractions also showed relatively high degrees of methoxylation early during ripening, and methoxylation decreased with continued ripening in both fruits. It seems that the methoxyl ester groups of polyuronide were affected little by dilute $\mathrm{HCl}$ extraction. The changes shown in

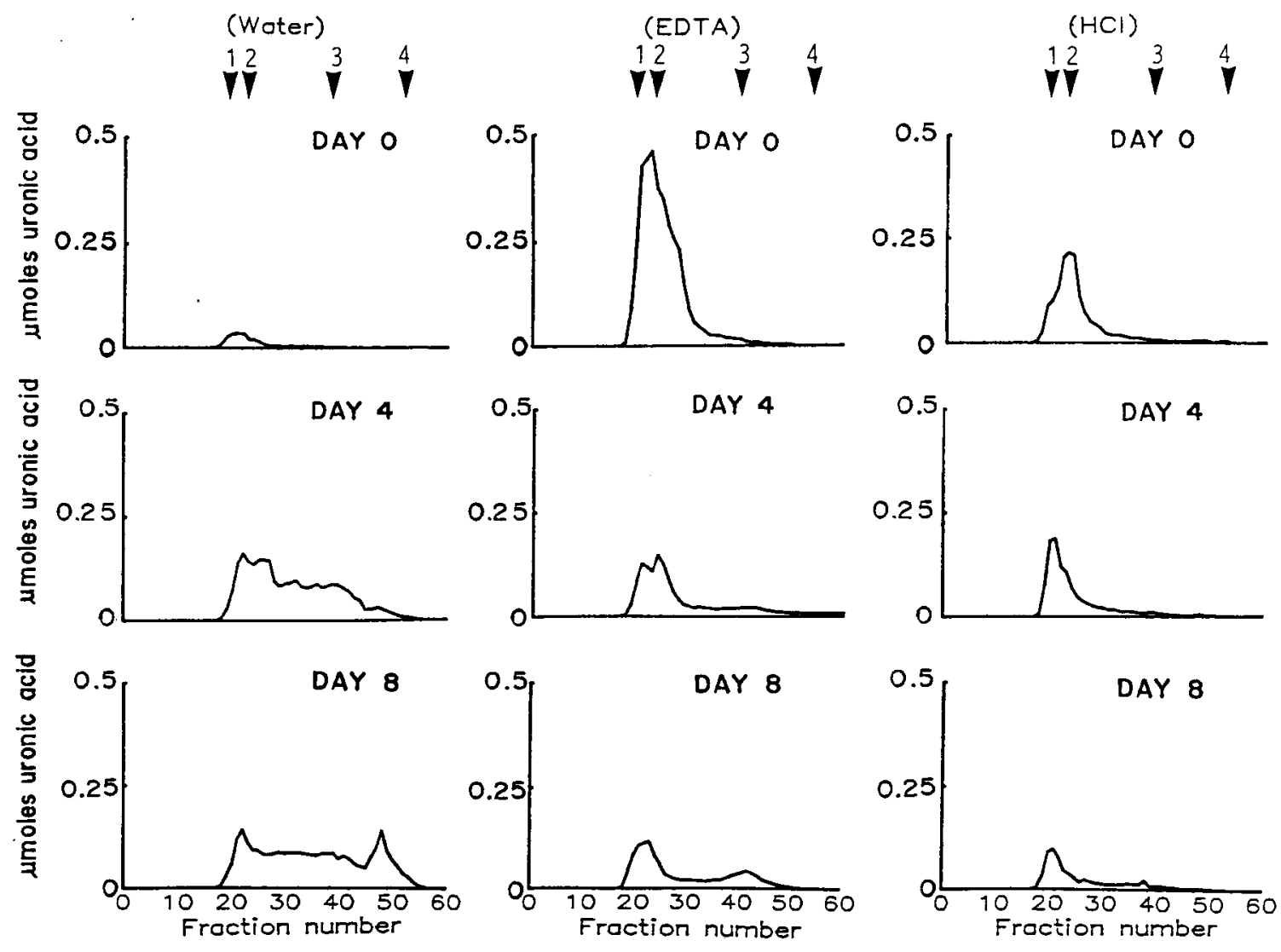

Fig. 4. Molecular weight distribution of polygalacturonides extracted from pear fruit cell walls. Polyuronides were fractionated by gel filtration chromatography (FPLC equipped with Superose $6 \mathrm{H} \mathrm{10/30}$ column). The column was equilibrated with $0.2 \mathrm{M} \mathrm{NaCl}$ in $0.015 \mathrm{M}$ citrate-sodium phosphate buffer ( $\mathrm{pH} \mathrm{5.5)}$. Samples $(200 \mu \mathrm{l})$ extracted from $0.2 \mathrm{~g}$ fresh pulp tissue were applied to the column and fractions of $0.4 \mathrm{ml}$ were collected. Column calibration was conducted with Blue dextran 2000 ( $\$$ ); Dextran T500 (500 kDa, $\left.\frac{2}{7}\right)$; Dextran T40 (40 kDa, $\$$ ); and galacturonic acid (194 $\mathrm{Da}, 4)$. 


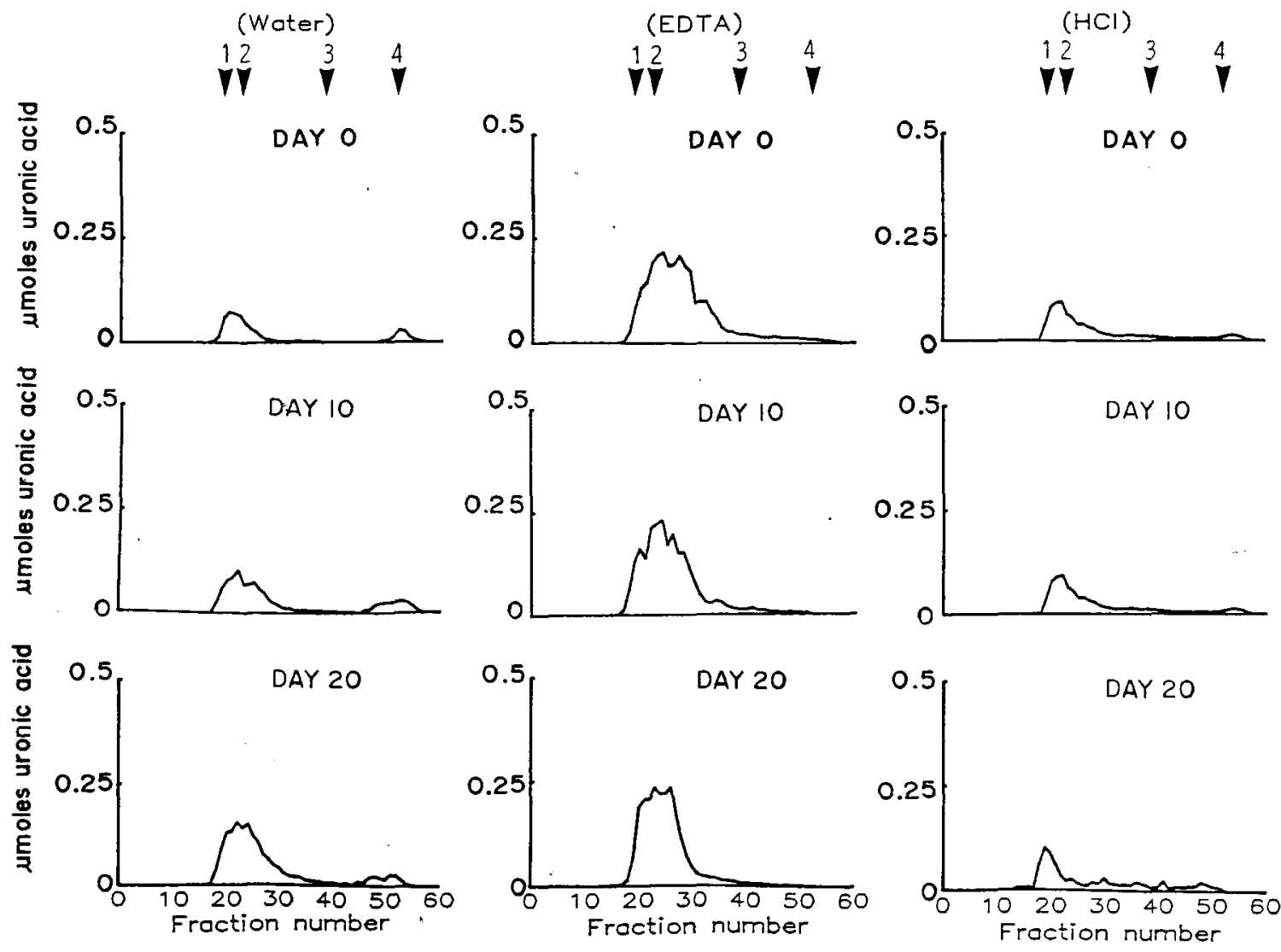

Fig. 5. Molecular weight distribution of polyuronides extracted from apple cell walls. Analytical conditions were the same as in Fig. 4.
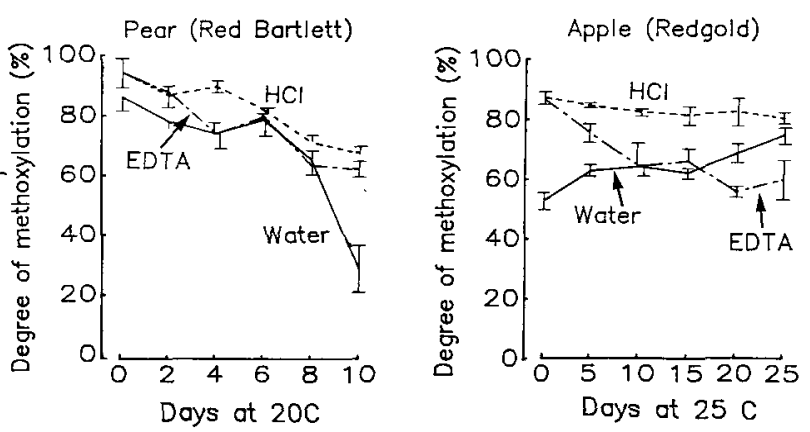

Fig. 6. Degree of methoxylation in polyuronides of pear and apples during ripening. Vertical bars are sEs.

Fig. 6 represent an average degree of methoxylation in polyuronide mixtures. Degree of methoxylation in the EDTA-soluble fraction of pear fruit at day 0 separated on a DEAE-Sepharose column is shown in Fig. 7. Polyuronides were eluted in order of their degree of methoxylation from the column by a linear gradient of $\mathrm{NaCl}$.

Changes in the elution profiles during softening showed similar patterns in apples and pears (Figs. 8 and 9). The EDTAand $\mathrm{HCl}$-soluble polyuronides at day 0 in both fruit were composed of a relatively wide range of polyuronides and degree of methoxylation compared to the water-soluble polyuronides. Polyuronides with a high degree of methoxylation and polyuronides not retained on the column were preferentially lost from the EDTA- and HCl-soluble fractions as the fruit ripened. Almost all water-soluble polyuronides were retained on the column. The degree of methoxylation in water-soluble polyuronide

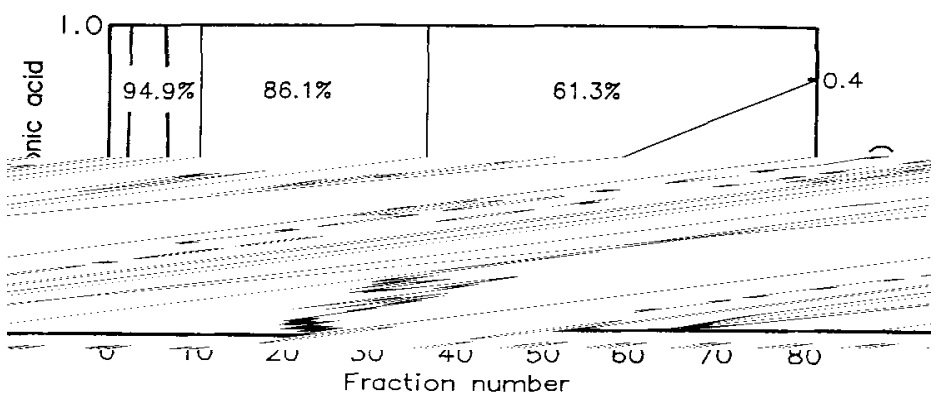

Fig. 7. Degree of methoxylation in polyuronides fractionated by a DEAE-Sepharose column. Pear polyuronides $(10 \mathrm{ml})$ extracted from $1.0 \mathrm{~g}$ of pear pulp tissue with EDTA solution were applied to a DEAE-Sepharose fast flow column $(10 \times 1.0 \mathrm{~cm})$ equilibrated with $0.05 \mathrm{M}$ acetate buffer $(\mathrm{pH} 5.0)$ and eluted by a linear gradient of $\mathrm{NaCl}(0$ to $0.4 \mathrm{M})$. Fractions of $2.0 \mathrm{ml}$ were collected and analyzed for uronic acid content and degree of methoxylation.

was lower than in polyuronides lost in the EDTA- and HClsoluble fractions. Lost EDTA- and HCl-soluble polyuronides are probably recovered as water-soluble polyuronides with a lower degree of methoxylation. The amount of polyuronides eluted with a high ionic strength (fraction 40-80) changed little during softening in both fruits.

Increased esterification of water-soluble polyuronide in ripening apples (Knee, 1978) and a decrease in the esterification of total polyuronide in ripening pears (Knee, 1982) agree with our results (Fig. 6). The degree of methoxylation appears to be important in pear and apple softening, and we have found that the amount of highly methoxylated polyuronide in EDTA- and $\mathrm{HCl}$-soluble fractions decreases and the slightly methoxylated 


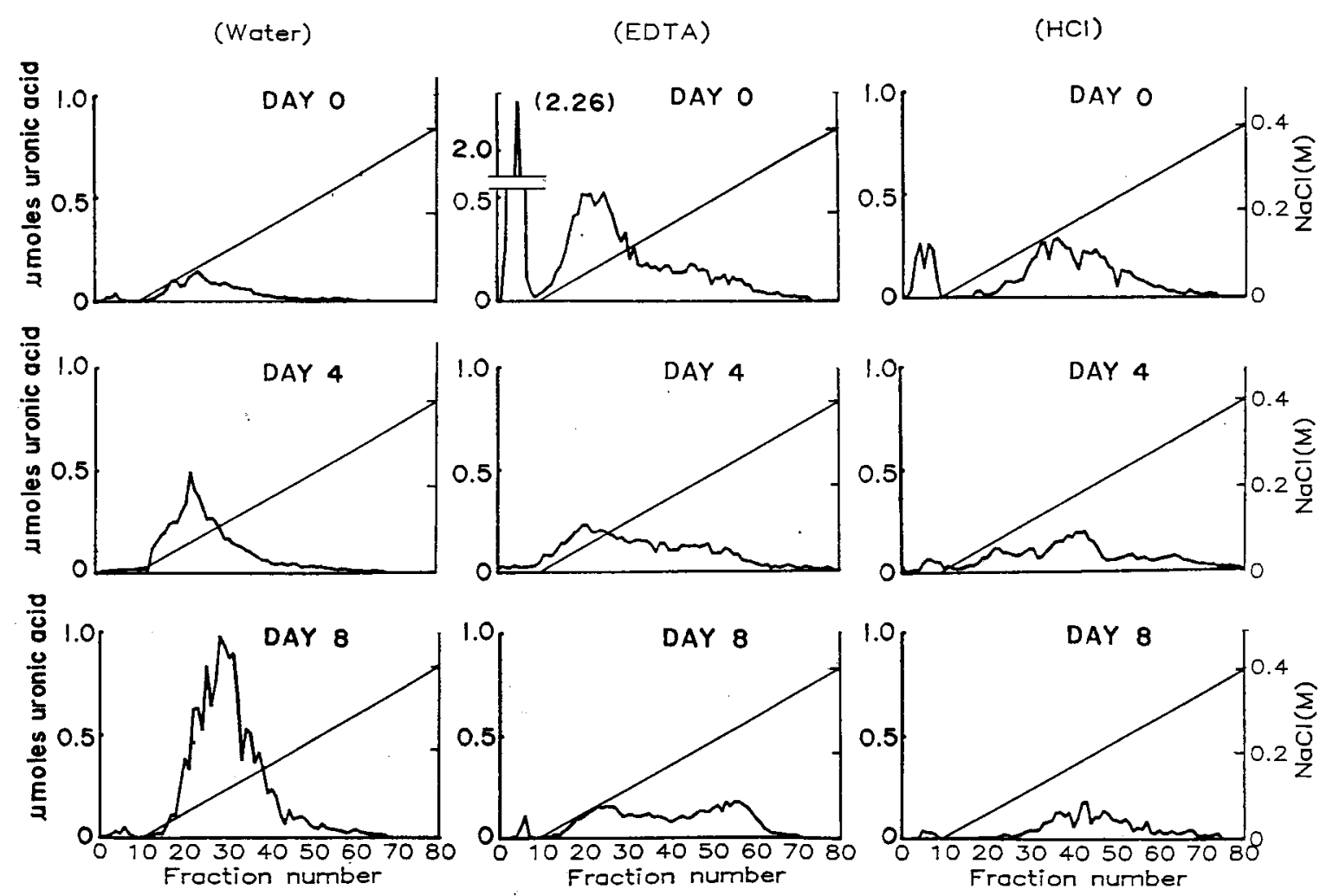

Fig. 8. Elution profiles of polyuronides extracted from pear cell walls by DEAE-Sepharose chromatography. Samples (10 ml) extracted from $1.0 \mathrm{~g}$ of fresh pulp tissue were applied to the column $(10 \times 1.0 \mathrm{~cm})$ and analyzed as in Fig. 7 .

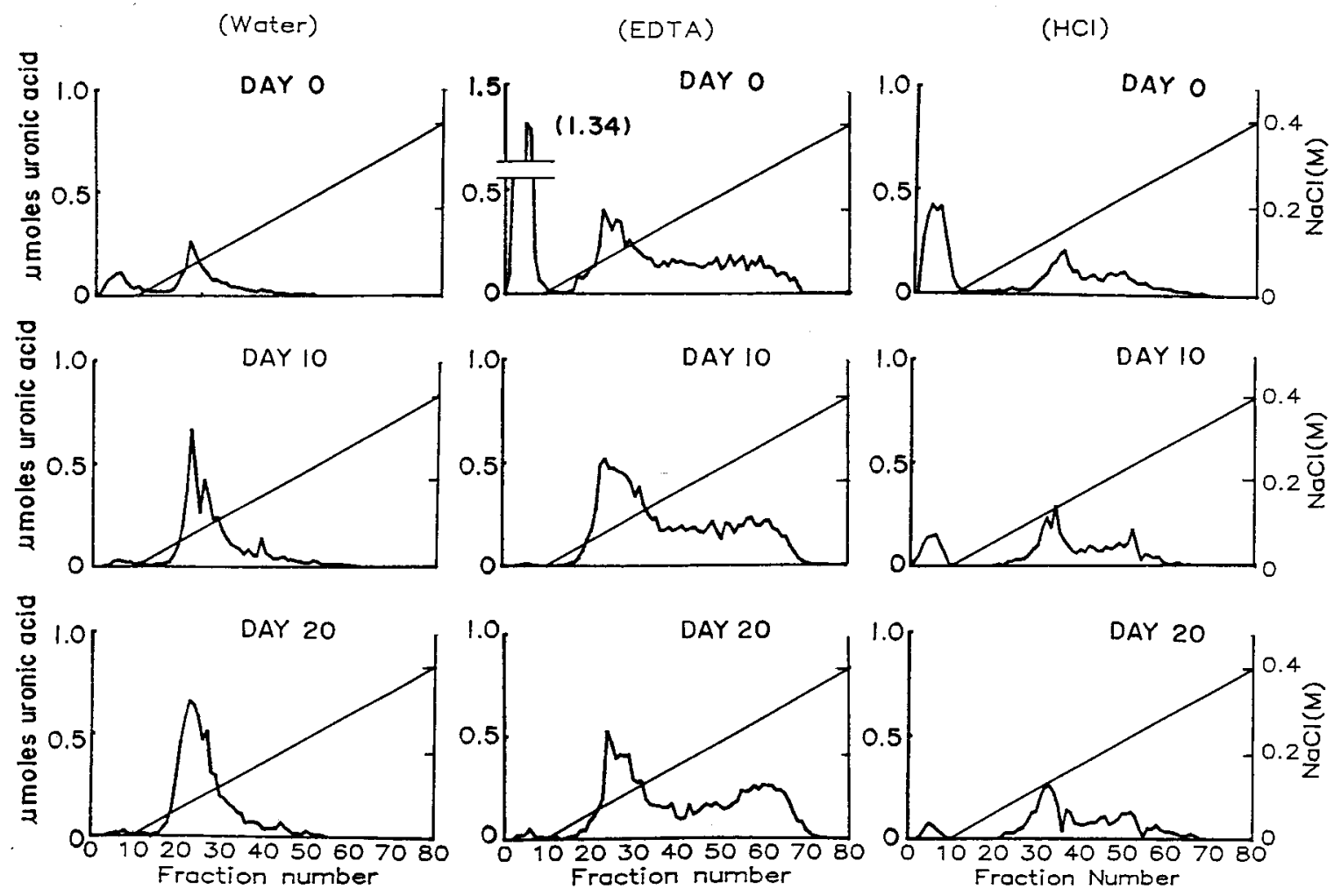

Fig. 9. Elution profiles of polyuronides extracted from apple cell walls by DEAE-Sepharose chromatography. Analytical conditions were the same as in Fig. 7.

polyuronides in the water-soluble fraction increase during softening in both fruits (Figs. 8 and 9).

The free carboxyl groups in polyuronide molecules frequently Pooviah et al., 1988). EDTA-soluble polyuronides are thought 
to be rich in such complexes. Polyuronides with a high degree of methoxylation can form only few calcium bridges and the complexes are labile. Then the molecules are de-esterified, the resulting negatively charged groups repel each other and cause swelling of the complexes. Polyuronides with a low degree of methoxylation form numerous calcium bridges and stable polyuronide complexes that are hardly affected when de-esterified. The EDTA-soluble fraction of pears and apples at day 0 contained several highly esterified polyuronides (Figs. 79). These polyuronides maybe solubilized not by the chelating effect of EDTA, but by the heating effect of hot buffer during extraction. Such fractions may not be involved in calcium bridging. The de-esterification of highly methoxylated polyuronide in EDTA- and HCl-soluble fractions may cause swelling of the polyuronide complex and lead to changes that induce its solubilization.

Pectinmethylesterase activity, which catalyzes the de-esterification of polyuronides, is present during fruit development and softening and often shows no correlation with sotening (Ahmed and Labavitch, 1980; Huber, 1983). The controlling mechanism in polyuronide de-esterification is still unclear.

de Vries et al. (1983b) suggested uneven intermolecular distribution of methoxyl groups in apple polyuronides. They also proposed a model for the apple polyuronide molecule in which the molecule consisted of homogalacturonan ("smooth" regions) and heterogalacturonan regions ("hairy" regions) (de Vries et al., 1981, 1982, 1983a). The degree of esterification of the heterogalacturonan regions was almost $100 \%$, while the long homogalacturonan regions (representing $>90 \%$ of the galacturonate residues) had an esterification of $\approx 70 \%$. Consequently, the polyuronides that disappeared in the EDTA- and $\mathrm{HCl}$-soluble fractions in apple fruit, as shown in this study, may be "hairy" regions. Polyuronides that contain high amounts of side chains may preferentially de-esterify during softening. Dick and Labavitch (1989) reported that the major type of watersoluble polyuronides during ripening of 'Bartlett' pears was homogalacturonan and also demonstrated that much of the polyuronide that becomes water-soluble during ripening is neutralsugar-rich. However, Redgwell et al. (1990 and 1991) deduced that the preferential release of a slightly branched part of the rhamnogalacturonan backbone of pectic substances occurs during kiwifruit [Actinidia deliciosa (A. Chev.) E.F. Liang et R. Ferg. var. deliciosa] softening. Neutral-sugar metabolism may also be involved in polyuronide solubilization during softening.

Our results with pears and apples suggest de-esterification of polyuronides with a high degree of methoxylation as a possible mechanism for solubilization of the polyuronide during softening rather than depolymerization of polyuronides. Polyuronides with a high degree of methoxylation may be side-chain neutralsugar-rich polyuronides, as suggested by de Vries (1983b) for apples. We did not analyze the sugar composition of the polyuronides in this study, and further information about the structural changes of polyuronides, including the changes in neutral-sugar composition of the polyuronides that preferentially solubilize at the initial phase of fruit softening, is needed.

\section{Literature Cited}

Ahmed, M. and J.M. Labavitch. 1980. Cell wall metabolism in ripening fruit. II. Changes in carbohydrate-degrading enzymes in ripening 'Bartlett' pears. Plant Physiol. 65:1014-1016.

Barnes, M. and B.J. Patchett. 1976. Cell wall degrading enzymes and the senescent strawberry fruit. J. Food Sci. 41:1392-1395.

Bartley, I.M. 1978. Exo-polygalacturonase of apple. Photochemistry $17: 213-216$.
Blumenkrantz, M. and G. Asboe-Hansen. 1973. New method for quantitative determination of uronic acids. Anal. Biochem. 54:484-489.

Christopher, J.S.S., C.F. Watson, P.C. Morris, C.R. Bird, G.B. Seymour, J.E. Gray, C. Arnold, G.A. Tucker, W. Schuch, S. Harding, and D. Grierson. 1990. Inheritance and effect on ripening of antisense polygalacturonase gene in transgenic tomatoes. Plant Mol. Biol. 14:369-379.

de Vries, J.A., F.M. Rombouts, A.G.J. Voragen, and W. Pilnik. 1982. Enzymatic degradation of apple pectins. Carbohydrate Polymers 2:25-33.

de Vries, J.A., F.M. Rombouts, A.G.J. Voragen, and W. Pilnik. 1983b. Distribution of methoxyl groups in apple pectic substances. Carbohydrate Polymers 3:245-258.

de Vries, J.A., C.H. den Uijl, A.G.J. Voragen, F.M. Rombouts, and W. Pilnik. 1983a. Structural features of the netural sugar side chains of apple pectic substances. Carbohydrate Polymers 3:193-205.

de Vries, J.A., A.G.J. Voragen, F.M. Rombouts, and W. Pilnik. 1981. Extraction and purification of pectins from alcohol insoluble solids from ripe and unripe apples. Carbohydrate Polymers 2:25-33.

Dick, A.J. and J.M. Labavitch. 1989. Cell wall metabolism in ripening. fruit. IV. Characterization of the pectic polysaccharides solubilized during softening of 'Bartlett' pear fruit. Plant Physiol. 89:13941400 .

Giovannoni, J.J., D. DellaPenna, A.B. Bennett, and R.L. Fischer. 1989. Expression of a chimeric polygalacturonase gene in transgenic rin (ripening inhibitor) tomato fruit results in polyuronide degradation but not fruit softening. Plant Cell 1:53-63.

Gross, K.C. and C.E. Sams. 1984. Changes in cell wall neutral sugar composition during fruit ripening: A species survey. Photochemistry 23:2457-2461.

Hobson, G.E. 1962. Determination of polygalacturonase in fruits. Nature 195:804-805.

Hedge, J.E. and D.T. Hofreiter. 1962. Phenol-sulfuric acid colorimetric method, p. 388-389. In: R.L. Whistler and M.L. Wolfram (eds.). Methods in carbohydrate chemistry. Academic, New York.

Huber, D.J. 1983. The role of cell wall hydrolyses in fruit softening. Hort. Rev. 5:169-219.

Huber, D.J. 1984. Strawberry fruit softening: The potential roles of polyuronides and hemicelluloses. J. Food Sci. 49:1310-1315.

Knee, M. 1973. Polysaccharide changes in cell walls of ripening apples. Photochemistry 12:1543-1546.

Knee, M. 1978. Metabolism of polymethylgalacturonate in apple fruit cortical tisue during ripening. Photochemistry 17:1261-1264.

Knee, M. 1982. Fruit softening. II. Precursor incorporation into pectin by pear tissue slices. J. Expt. Bot. 33:1256-1262.

Knee, M., J.A. Sargent, and D.J. Osborne. 1977. Cell wall metabolism in developing strawberry fruit. J. Expt. Bot. 28:377-396.

Lester, G.E. and J.R. Dunlop. 1985. Physiological changes during development and ripening of 'Perlita' muskmelon fruit. Scientia Hort. 26:323-331.

McCollumn, T.G., D.J. Huber, and D.J. Cantliffe. 1989. Modification of polyuronides and hemicelluloses during muskmelon fruit softening. Physiol. Plant. 76:303-308.

Mitcham, E.J., K.C. Gross, and J.N. Timothy. 1989. Tomato fruit cell wall synthesis during development and senescence. Plant Physiol. 89:477481.

Nawa, Y., H. Hosoda, and M. Kuroki. 1980. Extraction, concentration, partial purification and properties of exo-type polygalacturonase from Bartlett pear. Rpt. Natl. Food Res. Inst. 37:67-75.

Neal, G.E. 1965. Changes occurring in the cell walls of strawberries during ripening. J. Sci. Food Agr. 16:604-611.

Pilnik, W. and D.J. Voragen. 1970. Pectic substances and other uronides, p. 53-87. In: A.C. Hulme (ed.). The biochemistry of fruits and their products. Academic, New York.

Pooviah, B.W., G.M. Glenn, and A.S.N. Reddy. 1988. Calcium and fruit softening Physiology and biochemistry. Hort. Rev. 10:107-151.

Redgwell, R.J., L.D. Melton, and D.J. Brasch. 1990. Cell wall changes in kiwifruit following post harvest ethylene treatment. Photochemistry 29:399-407. 
Redgwell, R.J., L.D. Melton, and D.J. Brasch. 1991. Cell-wall polysaccharides of kiwifruit (Actinidia deliciosa): Effect of ripening on the structural features of cell wall materials. Carbohydrate Res. 209:191-202.

Rigney, C.J. and R.B.H. Wills. 1981. Calcium movement, a regulating factor in the initation of tomato fruit ripening. HortScience 16:550-551.

Smith, C.J.S., C.F. Watson, J. Ray, C.R. Bird, P.C. Morris,, W. Schuch, and D. Grierson. 1988. Antisense RNA inhibition of poly- galacturonase gene expression in transgenic tomatoes. Nature 334:724726.

Suwwan, M.A. and B.W. Pooviah. 1978. Association between elemental content and fruit ripening in rin and normal tomatoes. Plant Physiol. 61:883-885.

Wanner, S.J. and H.L. Bloom 1977. Characteristics of tomato cell wall degradation in vitro: Implication for the study of fruit-softening enzymes. Plant Physiol. 60:207-210. 